\title{
Rising Insecurity and Its Implications on Sustainable Development in Nigeria
}

\author{
Ibitoye, Majekodunmi Olusesan [Ph.D] \\ Department of Political Science and International Diplomacy, School of Social \\ and Management Sciences, College of Sciences, Bamidele Olumilua University \\ of Education, Science and Technology, Ikere-Ekiti., Ekiti State, Nigeria
}

\begin{abstract}
This study focuses on the rising insecurity and its implications on sustainable development in Nigeria. Undoubtedly, Nigeria has enormous security challenges owing to the prevalence of political, economic, social, cultural and ethnic crises right from when it became independent and sovereign state till date. The hope that the situation will improve someday has always been dashed with the deepening, intensification, escalation, exacerbation, spread and increasing prevalence of insecurity cases across the length and breath of the nation on a weekly or daily basis. Hence, the issue of security promotion should not be treated with levity. This is because without security, local, state and national development cannot be achievable, even the individuals, families, communities and the entire nation cannot make any meaningful development not to talk of sustaining it. The study reveals that family neglect, unemployment, corruption, poverty, leadership debacle, religious intolerance, ethnicity, etc, are responsible for this malady. It also discusses how insecurity has negatively affected all the sectors of the economy, individuals/groups and the entire nation at large. It is against this background that this paper recommends that every Nigerian both the government and the governed must sincerely look inward in order to resolve amicably some of the factors responsible for this problem of insecurity politically through the provision of employment opportunities, poverty reduction strategies, fairness, equity and justice, creating enabling environment, among other things. The study adopts the main tenets of structural-functionalism theory as the theoretical framework to analyze this work while it utilizes secondary sources of data with content analysis as its methodology.
\end{abstract}

Keywords: Security, Insecurity, Development, Sustainable Development and Nigeria.

DOI: $10.7176 /$ RHSS/11-23-04

Publication date: December $31^{\text {st }} 2021$

\section{Introduction}

Security remains the most important preoccupation of all human beings in any part of the universe as survival is said to be the first priority for mankind. In view of this observation and conviction, the importance of security cannot be over stated in any given political community. It is this conception that Thomas Hobbes used to justify the existence of an absolute form of government [The Leviathan] in his native England. He argued that a strong and unchallenged government was needed in order to ensure the safety of life which was otherwise endangered in a competitive community without anyone to provide law and order. Therefore, the political community which resulted from the social contract entered into by the individuals had the sole purpose to guarantee the safety of life. The substance of this social contract theory is that, the state is the result of an agreement entered into by men who originally had no governmental organization-which implies the division of the world into two periods namely: The period before the state was instituted and the period after. The first period he called state of nature, while he referred to the second as political society [Hobbes, 1651].

In support of the above position as canvassed by Thomas Hobbes, section 14[1] of the 1999 Constitution of the Federal Republic of Nigeria [as amended] states that "the security and welfare of the people shall be the primary purpose of the government [FGN, 1999]. Misillegas, Monor, and Rees [2003] also observed that "providing internal security for citizens is among the essential public goods any state has to deliver and ranks high among its primary sources of legitimacy". This therefore suggest that it is mandatory, for each state of the federation to provide the basic necessities for livelihoods such as education, health, human rights protection and other democratic institutions in order to establish peace, security and harmony as well as to avoid all sort of insecurity that can possibly hinder sustainable development.[Mbachu,2019].

Without prejudice, it is now a tradition for any responsible and responsive government to ensure that the quality of human living condition reaches an acceptable standard as well as creating opportunities that could actually promote sustainable development. However, all efforts by the federal and state governments to put an end /and/or to minimize this problem of insecurity has not yielded the desired result as the cases of assassination, ritual murder, banditry, kidnapping, wanton destruction of lives and properties, among others, continue to be on the high side on daily basis with consequent negative effects on the political and socio-economic well-being of the individuals and the nation at large, hence, the physical and psychological damage being experienced by Nigerians are unquantifiable. For instance, the EndSARS protest was a vector for broader dissatisfaction with the 
political class as there is widespread disillusion and discontent over the state of the economy, insecurity and the political system [Ogunmodede,2020]. Therefore, the apparent inability of successive administrations to adequately tackle the lingering national security crisis necessitates this research work and suggestions shall also be made so as to improve on the security and culture of sustainable development in Nigeria.

\section{Conceptual Clarifications}

In this part of the work, efforts will be made to conceptualize the basic concepts which the study set out to explore viz: security, development and sustainable development. We must also bear in mind that these concepts are not always easy to define because of the inherent dangers in giving a concise definition(s). However, we shall arrive at some working definitions that will help to simplify the understanding of these concepts.

\section{Security}

According to Akinade [2018: 137] security can be best understood in its political connotation as all forms of devices, machinery, precautions and arrangements established by government to guarantee peace and corporate existence of the nation as well as to give people effective freedom from danger, risk, harm, doubt, accident, violence and undue anxiety. In analyzing the same concept, Bellany [1981: 102] asserts that security itself is a relative freedom from war coupled with a relatively high expectation that defeat will not be a consequence of any war that should occur. Calthers [2010] further sees security as the totality of the nation's equilibrium state which needs to be maintained so that the nation can carry out its normal function without unnecessary interruption from anywhere.

\section{Development}

According to Walter Rodney, development is a many-side process. At the level of the individual, it implies increased skills and capacity, greater freedom, creativity, self-discipline, responsibility and material well-being [Rodney, 1969]. One thing which could be derived from the foregoing definition is that development goes beyond economic indicators. Todaro was also of this view as he defined development as a multi-dimensional process involving the re-organization and re-orientation of the entire economic and social system. This involves in addition to improvement of income and output, radical changes in institutional, social and administrative structures as well as in popular attitudes, customs and beliefs [Todaro, 1982].

The main contention of Todaro is that development is both a physical process and state of mind. The transformation of institution is one aspect, the other aspect is that the thinking of people must change. By and large, development could be seen as the comprehensive economic, social, cultural and political process which is aimed at constant improvement of the well-being of the entire population and of all individuals on the basis of their active, free and meaningful participation in development and the fair distribution of benefits resulting therefrom [Aladeitan, 2012].

\section{Sustainable Development}

The term sustainable development rose to significance after it was used by the Brundtland Commission in its 1987 report "Our Common Future". In the report, the Commission coined what has become the most oftenquoted definition of sustainable development as: "development that meets the needs of the present without compromising the ability of future generations to meet their own needs [Ujo, 2015]. This concept is conceptually broken into three constituent parts: environmental sustainability, economic sustainability and socio-political sustainability. It is all about equity and equality of opportunities for human well-being [Aladeitan, 2012].The term contains within it two important concepts: The first one being the concept of' 'needs' in particular, the essential needs of the world's poor, to which overriding priority should be given to and the idea of limitations imposed by the state of technology and social organization on the environment's ability to meet the present and future needs.

\section{Nexus between Security and Sustainable Development}

There seems to be a systematic relationship between security and sustainable development in every nation of the world, Nigeria inclusive. It is against this background that governments all over the world as well as international institutions are becoming more and more concerned about the need to integrate security and development programmes in their policies and that is why the managers of our politics and economy and other stakeholders and/or collaborators must ensure that there must be peace in our nation. Without doubt, security is a facilitator to development as there can be no sustainable development without peace and security in any economy. Hence, it is imperative that the preservation of mankind through peaceful co-existence cannot be undermined.

As rightly observed by Jegede [2012] peaceful co-existence is fast eluding Nigeria as a nation-state, a condition that has prohibited the development of the nation in all ramifications. To this extent, Nigeria urgently requires security promotion at this moment considering the religious, sectional, political, social and economic problems of various dimensions facing her. This is to further confirm that security and development are strongly related and interlinked. 


\section{Theoretical Framework: Structural-Functionalism Theory}

The study adopts structural-functionalism theory as the theoretical framework for its analysis. The choice of this theory is based on the fact that the theory would be an important tool in explaining issue that has to do with the structure of the society. The major proponents of this theory are; Emile Durkheim, Talcott Parsons, Herbert Spencer, Robert Merton, among others. Structural-functionalism theory posits that society is a system of interconnected parts that work together in harmony in order to maintain a state of balance and social equilibrium for the whole. According to this theory, each of the parts contributes important functions to the system in order to guarantee the general well-being of the entire society [Ritzer, 2012]. The submission here is that both the government [legislative, executive and the judiciary] and the governed [the elites and the masses] must be alive to their responsibilities in order to keep the system functioning effectively.

However, it is crucial to stress that the Nigeria's security problem has consistently assumed a more compelling dimension in the light of the failure of each of the parts of the system to effectively contribute their quotas to a certain degree of order and stability required for survival of the society. Hence, the nation has not witnessed any significant changes in the national security in recent time contrary to the expectations of the majority as Nigerians are daily subjected to intolerable suffering and this explains why this framework of analysis is best suitable for this work.

\section{Causes of Insecurity in Nigeria}

Many factors have been identified by public affairs analysts as well as scholars as being responsible for the state of insecurity in Nigeria. Some of the factors are as discussed below:

Family Neglect: Musa and Gele [2008] sees family as the smallest unit of socialization that consist of father, mother and biological sons and daughters or adopted children to be cared for by the parents. The family is seen as the center of peace where peace education will start in all societies of the world if relative peace is to be achieved. Ukadike as cited in Musa [2010] asserted that the family is charged with the responsibility of imparting in the youth desirable moral values, good attitudes, virtues such as honesty, hardwork, diligence, purposefulness, righteousness and creativity, respect and obedience. Under this condition, a well-behaved and trained child is not likely to be involved in any kind of violence that will jeopardize the peace of the society. The point being made here is that every family is expected to take as a matter of responsibility the proper education, training and general care of his family as the development of the family is the development of the community and the nation at large. However, many families have failed in this important aspect, hence, the security challenges facing the nation.

Unemployment: From all indications, the problem of unemployment has forced many Nigerians into various activities that constitute a threat to the country's security and subsequently against the socio-economic development. The dimension that is most worrisome and dangerous is the increase in the number of primary, secondary and post-secondary school graduates that swell the already saturated employment market. Besides, the situation is more complicated by retrenchment in both public and private sectors in the past and present, a situation that is fast becoming significant in the emerging structure of unemployment. According to Osamwonyi[2009] the rate of unemployment has attained an enormous proportion with rapid inflow of crimes. Corroborating this view, the National Bureau of Statistics[2020] records shows that as of the second quarter of 2020, the youth unemployment rate in Nigeria has increased from 40.80 percent to 53.40 percent in the fourth quarter of 2020[ www.macrotrends.net].

Corruption: Within the context of politics and governance, corruption is seen as the "... abuse of power and public trust and misuse of official positions and responsibilities for self-serving objectives whether for personal, private or group gain'[Jega,2005:1]. No doubt, corruption has permeated the entire Nigeria's political space and socio-economic systems and its magnitude has been on the increase on daily basis inspite of the government's efforts to fight the 'monster' through the establishment of Economic and Financial Crimes Commission [EFCC], and Independent Corrupt Practices and other Related Offences Commission [ICPC]. Without any form of contradiction, Nigeria still remained one of the most corrupt countries in the world as Transparency International[TI] ranked Nigeria in its 2020 global Corruption Perception Index [CPI] as the twenty-six 26 most corrupt nation out of one hundred 100 countries [TI, 2020]. The desire to acquire illicit wealth and the need to satisfy emotional insecurity and instability, among other factors, has motivated many Nigerians to be involved in corruption. Most of the people that find themselves at the top echelon of governance are often found to be corrupt as the funds that are budgeted for development are always being mismanaged, misappropriated or embezzled. The result has been total neglect of infrastructural facilities, abject poverty, frustration, social unrest, violence, ethnic militans, among others [Ibitoye, 2004]. This trend therefore necessitates the need for the three tiers of government [federal, state and local governments] and all corporate bodies and individuals to cooperate with one another in the essential task of eradicating corruption as an indispensable requirement in order to reduce the disparity in the standard of living and meet the needs of the majority of the people.

Poverty: Makama and Amos [2013] sees poverty as humiliating dependence, a state of deprivation, lack of basic necessities of life, inability to satisfy the basic requirements for human survival and inadequate satisfaction of 
the basic needs of life. Be that as it may, the high level of poverty with its attendant high crime rate in Nigeria has always been a source of great concern not only to the government but to all stakeholders because of the inherent dangers embedded in it .It is no longer news that poverty is on the increase in Nigeria as about $86.9 \mathrm{~m}$ Nigerians are currently living in severe poverty [ Nwokoji,2021]. It has remained just at the point of its condemnation without proactive measure to address it adequately. Although, poverty is not an excuse for engaging in the act of criminality that breach the peace of the society, the reality, however, is that, poverty is a remote factor, for instance, it is the citizen's poverty that makes them to be easily carried away by a Greek 'gift' from the sponsors of violence, election rigging social injustice, economic sabotage, among others [Dangana, 2012].

Continual Decaying of Infrastructural Facilities: Infrastructural facilities are important instrument of development. These include among other things, solidly constructed and well maintained roads, hospitals, telecommunication services, buildings of nice architectural design, e.t.c. Besides, certain public utilities like steady supply of electricity and portable drinking water are vital necessities [Ibitoye, 2004]. Without any iota of doubt, successive governments have failed to keep to their promises in this particular area. One of the major reasons accountable for this abysmal failure in tackling the infrastructure crisis is the fact that it has not always been giving the priority it deserves. Secondly, due to corruption. At times funds that are allocated to these infrastructures are often embezzled with impunity. Thirdly, the politicization of the infrastructural development is also seen in the appointment of heads of ministries and parastatals related to the provision of infrastructure. Some of the most crucial ministries like the Federal Ministry of Works and Housing, Ministry of Transport and Ministry of Health are always headed by members of the ruling party who often see their appointments as a personal reward rather than a national call to service. Such assumptions are apparently justified by the inability of the government to hold these officials accountable for non-performance despite glaring evidence of their ineptitude [Alabi, 2009].

Exploitation/Injustice: The exploitative character of the Nigerian state constitutes a serious threat to the national security whose fallout has always hindered sustainable development. The unjust structuring of the Nigerian federalism by the British colonial masters which has given the worth unfair advantages over the South in the distribution of the benefits of natural resources and allocation of power have not been properly addressed several years after the country formally gained political independence. This perceived imbalance in power relations between the North and South is responsible for the age-long agitations by the Southern for a' redress of the uneven federal arrangement. The current legal battle between the Northern Governors and their counterparts in Rivers and Lagos States over the collection of Value Added Tax [VAT] in the latter's states is a classical example which must be wisely handled by the Supreme Court. Furthermore, the discovery of oil in the NigerDelta which is supposed to be a blessing has turned to be a curse as the region has remained under-developed in terms of infrastructural facilities. Both the Federal Government and the oil multinational corporations [MNCs] have not made much efforts in improving on the deplorable state of infrastructures in the Niger-Delta. Frustration and agony arising from this unpleasant situation often motivate the inhabitants especially the youth to turn to warlords or militants in order to disrupt the peace of the region through the vandalization of pipelines, kidnapping, violence and other criminal activities. Consequently, Chukwuebuka [2013] argues that despite the large sum of money Nigeria has made through oil exploration in the Niger-Delta, the region has not been adequately compensated. Thus, the Nigerian state rather than resorting to policies or programmes that could actually add values and promote the welfare of the majority in the region, the state continues to act otherwise, hence, the nation is threatened.

Leadership Debacle: The way and manner by which Nigeria got her independence actually affected the qualities of leaders that emerged shortly after the departure of the colonial masters [Ayoade, 1997]. The colonialists were not interested in the well-being of their subjects, the Nigerians but instead, they were more concerned about their economy and how to exploit them. Secondly, the independence was granted on the platter of gold. Hence, the 'emergency' leaders could not adequately addressed those problems associated with a young nation called Nigeria at that particular time. Unfortunately too, the trend was allowed to continue from generation to generation up till today. No wonder why the issue of nation-building has been an illusion. Chinua Achebe, in his book, "Trouble With Nigeria" [1981] supported the above view and argued persuasively that Nigeria had only succeeded in producing rulers as leaders. An examination of Nigeria's rulers from the postindependence era till date in buttressing this is like doing the obvious. Similarly, Ojukwu, in his work, 'Because I am Involved'[1989] opined that the real problem with Nigeria has been the failure of its leadership to embark upon, with courage and dogged determination, the urgent task of nation-building which implies a state of change that leads to progress or improvement in the state of well-being of the people. However, the attendant consequences has been political riots, violence, hunger, poverty, corruption, under-development and insecurity.

Geo-ethnicity Problem: This particular problem is as old as Nigeria herself. The reason being that the three major political parties that contested for the 1959 General elections were formed along ethnic lines-Action Group [A.G], Northern Peoples' Congress [NPC] and National Convention of Nigeria Citizens' [NCNC] were 
patronized by the majority of the Yoruba, Hausa and Igbo respectively [Ayoade,1997]. Without mincing words, it had constituted a major problem in the body politics of the nation. Of late, it has permeated virtually every sphere of human endeavor. At times in certain part of this country when transacting a business or seeking a favour, it is ethnicity all the way, even at government offices and parastatals. Under such a condition- How can a nation develop? Geo-ethnicity is one of the factors upon which disunity hinges and with disunity, crisis is inevitable while progress is stagnated. One finds out that there are imaginary boundaries constructed everywhere to establish 'us' and 'them'. Viewing the concept of 'home' in Nigeria is a different matter. For example, Is Nigeria home to all Nigerians or strictly their state of origin? Politically, the country came under one government some years ago, precisely 1914, yet ethnicity with its attendant problems still rears its ugly head among us and this factor partially explain why ethnic militias exist in all the geo-political zones of the federation. This includes:; Oodua People's Congress, Bakassi Boys, Egbesu Boys, Benue/Tiv Youth Movement, Jukun Youth Movement, Plateau Youth, Arewa Youth, Movement for the Actualisation of the Sovereign States of Biafra, etc. These bodies have become a factor in ethnic-religious and ethnic-communal crises in Nigeria, a serious challenge to our security system.

Religious Intolerance: To say that one of the most volatile problems facing Nigeria today is religious intolerance is like reiterating the fact. Pronouncements credited to certain religious leaders who are supposed to be role models of good peaceful co-existence have not helped matters. Both religious bodies [Christians and Muslims], especially in the Northern part of the country have failed to tolerate each other thereby leading to incessant clashes claiming many lives and properties that worth millions of naira and sometimes unquantifiable. This country has witnessed quite a number of religious bitterness in forms of factionalization, "cold war", interreligious groups or in form of outright riots like the case of Maitasine, Katsina, Kano. Kaduna, Bauchi riots in the 1980's. And again, between 22 and 23 May, 2002, over 300 lives were lost in clashes between Christians and Muslims over the proposed introduction of Islamic criminal code in Kaduna State [Ayinla, 2004]. In addition, from $2^{\text {nd }}$ to $4^{\text {th }}$ of May, 2004 between 500 and 600 people, mostly Muslims were massacred while 49 vehicles, 210 houses were destroyed in a reprisal attack to February $23^{\text {rd }}$ attack in Yelwa, Plateau State [Bakoji and Onoja, 2004; Ayinla, 2005 and Shobayo, 2004], just to mention few of them. In this part of the world, religious intolerance has in no small measure created a stumbling block to the peace and security of our dear country and the effects has always been unpalatable and devastating.

Proliferation of Arms and Ammunitions: The uncontrolled access to arms and ammunitions is worrisome and this explains why Nigerians are deeply concerned over the illicit trade, transfer and circulation of small arms and light weapons through our porous borders. Their excessive accumulation and uncontrolled spread in all parts of the country are having devastating humanitarian and socio-economic consequences especially in Northen states of the federation. For example, on the $19^{\text {th }}$ of July , 2021, an Alpha military jet was shot down by the militant groups which government calls " bandits" on Zamfara/Kaduna boundary area ; the infiltration of the Nigeria Defence Academy, NDA, fortress where two middle-level officers were reportedly killed and abduction of another by yet another group of armed hoodlums in fake military uniforms on Tuesday, August 24,2021 added to the parlous security situation in the country [www.vanguardng.com/2021/09/terrorist-attack-on-nda]. This shows that nowhere is safe anymore in the country.

\section{Effects of Insecurity on Sustainable Development}

The general rising insecurity across the nation has affected certainly all the sectors of the economy, be it educational, agriculture, health, just to mention a few of them. For instance, the educational sector which is regarded as the bedrock of socio-economic development is mostly affected as many pupils and students have been forced out of schools for fear of either being abducted for ransom or killed due to insecurity caused by the activities of Boko Haram and bandits in the Northern part of the country. The implication is grievous in the sense that a generation of citizens from the North will be incapacitated and unable to contribute meaningfully to the socio-economic and political growth and development of their states in particular and the nation at large.

The concept of sustainable development is informed by the need to sacrifice our today for tomorrow of our offspring such that we do not compromise the future of our children by our attitude and our consumption patterns today. However, with all sincerity of purpose, this task may be difficult to achieve in the face of security challenges. In other words, the solemn responsibility to protect and improve the environment for the benefit of the present and future generations through careful planning and management may not be feasible with the attendant rising insecurity in the nation.

The kind of agony, pain, depression, frustration and psychological torture arising from the security challenges are capable of making someone to lose interest in the task of nation's developmental efforts .Sometimes, one may feel that since the government has failed to perform that historic role of protecting and guaranteeing public safety, one may not see the need to perform his/her responsibilities to the state too and where such practice is allowed to manifest, sustainable development is under a threat.

Resources that ought to have been used for developmental purposes such as the provision of schools, 
electricity, pipe- borne water, hospitals, good roads, housing estates and probably used to set up industries that could provide job opportunities for the people are being used for buying weapons in order to fight insurgency or security matters. For instance, on the 28th August, 2017, the headquarters of the United States Department of Defence, the Pentagon informed the U.S Congress of the sale of Super Tucano A-29 ground attack aircraft and weapons to Nigeria to fight Boko Haram insurgency valued at \$593m[\#181bn] [Olukorede, 2018].

It also poses threat to the peace, unity and corporate existence of the country and without peace, unity and cooperation, the task of nation-building may be difficult to achieve. As succinctly put forward by Aladeitan [2012] by the nature of the strong connection between peace and development which has been vividly captured in the common saying that "there is no peace without development and there is no development without peace". According to him, both peace and development are so intertwined and can be described as Siamese twins with interdependence on each other. In summary, it could be argued that peace is a necessary condition for sustainable development and vice-versa.

Both local and foreign businessmen are gradually withdrawing and relocating to safe areas or countries within and outside the country due to insecurity and dwindling markets. This has consequently led to loss of jobs thereby deepening the existing unemployment rate with various multiplier effects on the society such as poverty, stealing, prostitution, thuggery, armed robbery and so on. On the other hand, government is equally losing certain amount of revenue from these businessmen in form of taxes which would have been used for developmental programmes so as to better the lives of the majority.

Insecurity has forced thousands if not millions of Nigerians to flee their ancestral homes for safety especially in the Northern part of Nigeria and this has resulted in an unprecedented humanitarian crisis. Since there is no adequate provision for this class of people - Internally Displaced Persons [IDP], they automatically become a threat to the general public in the nearest future. Why? Because the "survival of the fittest" instinct must surely manifest and in the cause of trying to satisfy this instinct, anything can happen, hence, sustainable development becomes a herculean task.

Insecurity is one of the biggest threat to food security in Nigeria as of today. While highlighting the important elements of food security, Idachaba [2006] opines that national food security can be said to exist when the majority have access to food at all times. Accordingly, access is described as a situation whereby the majority if not all people have real purchasing power to make entitlement on the available food. Accessible food must also be in sufficient quantity and quality to meet the normal and/or minimum nutritional requirements of daily calorie intake of [2450kcal/day] as recommended by the Food and Agriculture Organization [FAO] and World Health Organization [WHO] for healthy living. In addition, he observed that food security should be a permanent phenomenon rather than transitory and that food security should be based on locally produced food items. The pertinent question to be asked is that- How do we achieve food security when farmers are being constantly kidnapped for ransom or killed? Without any form of argument, the fear of being kidnapped or killed has adversely affected food production in Nigeria and this call for national deliberation and urgent remedy.

\section{Conclusion}

Security plays an important role in the life of a nation. This is because the attainment of a nation's full socioeconomic and political potentials depends to a greater extent on the level of security available. Consequently, national security must be a subject for political debate and of immediate concern for any national development programmes and the need to evolve strategies that are workable and sustainable. Inspite of the fact that she occupies a strategic position in the comity of nations in Africa, Nigeria is largely characterized by high prevalence of insecurity, a trend that is fast becoming dangerous and embarrassing as the invasion of Nigeria Defence Academy [NDA] cannot be easily forgotten in the political history of Nigeria.

In this study, we made an attempt to expose the systematic relationship between security and sustainable development. In doing this, we have discovered that peace forms an essential ingredients of sustainable development. That is to say, without peace, development cannot be achieved and sustained. Thereafter, we began to discuss some of the negative effects of insecurity on the individuals/groups and the entire nation. Efforts were also made to reveal some plausible reasons for this persistent insecurity problem in Nigeria and these includes; family neglect, unemployment, exploitation, injustice, corruption, poverty, leadership debacle, ethnicity, among other things. This study concluded that the issue of insecurity must be addressed wholistically for Nigeria to attain sustainable socio-economic development.

\section{Suggestions}

In order to avert the impending doom for the nation, the following suggestions are therefore recommended;

- Government must ensure that every citizen take as a matter of responsibility the proper education, training and general care of his family.

- Nigerian government should try as much as possible to ensure good governance that will reduce corruption through an independent judicial system that is impartial and fearless to deal with corrupt practices. 
- Emphasis should be laid on the provision of basic and essential infrastructures necessary for industrial take off that would certainly reduce unemployment problem.

- $\quad$ Pro-poor policies/ programmes should be vigorously pursued by all tiers of government [federal, state and local governments].

- Leaders must lead well and deprive themselves of the selfishness and minimalism into which they have immersed themselves. They must do their best to ensure that they desire a new and better Nigeria.

- The Nigerian system should be governed by the culture of mutual trust, love, co-operation, patriotism and nationalism as against ethnicity or primordial interest.

- Religious leaders should be more diplomatic and tactical in their pronouncements and be tolerant of each other.

- Since the majority who lives in the rural areas are farmers, government should therefore develop the agricultural sectors with attractive incentives so as to arrest the minds of the youth who are mostly involved in crimes.

- There is need for a broad-based global partnership in the ongoing battle against trans-border crimes including terrorism and piracy.

- Great nations are built on the strength of characters of the people. If Nigeria must come out of the present situation, every person must take responsibility; everyone must commit to do what he/she ought to do to his/her country. This is the basic moral obligation to the country.

\section{References}

Achebe, C [1981] Trouble With Nigeria. Enugu: Fourth Dimension.

Akinade [2018] "Exploring security, Legal and Ethical Issues in Kidnapping. Hostage-Taking and Communal killings", Security and Intelligence. Review Journal of Contemporary Security and Intelligence Studies (2), 137.

Alabi, D.O [2009] The Nigerian Political Economy [1983-2003].Kaduna: Joyce Graphics Printers and Publishers.

Alaidetan, L [2012] "Legal and Institutional Framework for Peace and Sustainable Development" In Egbewole, W.O, Etudaiye, M.A and Olatunji, O.A [Eds] Law and Sustainable Development in Africa. Ilorin: Al Fattah Publication Ltd pp 39-40.

Ayinla, S.A [2004] "Managing Religious Intolerance and Violence in Nigeria:. Problems and Solutions" A Paper Presented at the National Conference On Social Problems, Development and the Challenges of Globalization, Organized by the Department of S.ociology and Anthropology, Obafemi Awolowo, University, Ile -Ife, 16th -17th June.

Bakoji, S and Onoja, A[2004] "Who Will Tame Plateau's Ethno- Religious Crisis" Daily Independent, 14th May.

Bellany, I [1981] “Towards a Theory of International Security”. Political Studies (29), 1

Calthers, M [2010] Intelligence Gathering and Surveillance. Abuja: Mark Press Limited.

Chukwuebuka, E.Z [2013] "National Security and Oil Pipeline Vandalization in Nigeria: A Cause Effect Analysis". In Okpaga, A [Ed] Gender, Good Governance and Organizational Management in Nigeria. Makurdi: Microteacher and Associates. p99.

Corruption Perception Index [2020]. Assessed on the 2nd October, 2020.

Dangana, J [2012] Poverty Man's Greatest Enemy. Kaduna: First Pyramid Digital Publishing Co. Ltd.

FGN [2009] Constitution of the Federal Republic of Nigeria. Abuja: Government Press.

Hobbes, T [1651] Levithan. Deut: Everyman Library.

Ibitoye, M.O [2004] Introduction to Politics of Development and Under-development. Akure:Radiants Publishers Ltd.

Idachaba, F.S [2006] Good Intention Are Not Enough. Collected Essays on Government and Nigerian Agriculture. Vol. 1: The Agricultural Policy Process. Ibadan: University Press Plc.

Jega, M.A [2005] “The Fight Against Corruption and Democratization in Nigeria: How Little and How Late?” A Paper Presented as a Keynote Address at the Panel Discussion on Democratization and the Challenges of Good Governance in Nigeria. Organized by the Forum for Democracy and Good Governance. House of Representatives at Yar'adua Centre, Abuja, Monday, May 16

Jegede, O [2012] "Women, Peace Promotion and National Development: Portrait of AbigailAs an Effective Communication in the Bible". Nigerian Association for Biblical Studies (3), 291-292.

Makama, G.A \& Amos, A.P [2013] "Democracy and Mass Poverty Reduction in Nigeria".InModibbo, A.S and Adadu, Y.A [Eds] Democracy and Development In Africa.Keffi: Department of Political Science, Nasarawa State University p 31.

Mbachu, O [2009] "Democracy and National Security" .In Mbachu, O and Eze, M.C [Eds] Democracy and 
National Security: Issues, Challenges and Prospects Kaduna: Medusa Academic Publishers pp 3-28.

Misillegas, Y, Monar, J \& Rees, W [2003] The European Union and Internal Security: Guardian of the People. New York: Palgrave Macmillan.

Musa, S.I [2010] Peace, Education, Security and Social Studies in Nigeria. Nigerian Journal of Social Studies 13 [1\&2], 195.

Musa, S.I \& GELE, G.N.S [2008] "Family, School and Community Participation in the Development of the Life of the Nigerian Child." A Paper Presented at the $24^{\text {th }}$ National SOSANConference, University of Abuja, Abuja.From 2nd-5th October.

Nwokoji, C [2012] "Why Nigerians are Suffering Despite Economic Growth?" Nigerian Tribune, 4th October.

Ogunmodede,C.O [2020] How the EndSARS Movement Upended Politics as Usual in Nigeria https://www.worldpoliticsreview.com/articles/29170/how-the-endsars-movement-upended-nigeriapolitics.

Ojukwu, O [1989] Because of I am Involved.Nigeria: Spectrum Book Ltd.

Olukorede, A.S [2018] "Terrorism, Urban Violence and Threat of Kidnapping: Problem to National Security". Journals of Contemporary Security and IntelligenceStudies.2[2], 64.

Osamwonyi, L.O [2009] “Training Manual for Graduate Entrepreneurial Scheme.”Ministry of Commerce and Industry, Edo State.

Ritzer, G (2012) Sociological Theory. New York: McGraw Hills Publishers.

Rodney, W [1976] How Europe Under-developed Africa.London: Boyle-Looverture.

Shobayo, I [2004] "Sledgehammer on the Plateau" Saturday Tribune, May 22.

Todaro, M.P [1982] Economics for a Developing World. London: Longman.

Transparency International [2020] Transparency International Annual Report.

Ujo, A.A [2015] Theory and Practice of Development Administration. Kaduna: Joyce Grassphic Printers \& Publishers.

www.macrotrends.net.Assessed on the 10th October, 2021.

www.vanguard.com/2021/09/terrorist-attacks-on-nda. Assessed on the 12th October, 2021. 